\title{
Gambaran Tawakal Pada Mahasiswa Yang Memiliki Penyakit Kronis
}

\author{
Munirah, Yulia Hairina, dan Mubarak \\ Universitas Islam Negeri Antasari Banjarmasin
}

\begin{abstract}
Chronic illness is a dangerous disease that cannot be underestimated or ignored because it can cause death at any time, but this is not an excuse for some students at UIN Antasari where they live and continue their studies well even though in their bodies there are diseases that can cause death, this is because they choose to trust God because with trust they can live their lives better. So from that researchers are interested in examining the description of the trust process in students who have chronic diseases at UIN Antasari Banjarmasin and factors that influence attitudes trust. This research uses a qualitative approach. The subjects in this study were 3 students of UIN Antasari who had chronic diseases. Data collection in this study was obtained using Anecdotal Record observation techniques, and semi-structured interviews. After the data is collected, it is then analyzed with the stages of editing, coding, description and concluding data. Based on the results of this study, there are several aspects that arise after making trust, such as the emergence of calm and peace, generate strength, Rida, and the emergence of hope. The factors that influence tawakal behavior are, first, the environmental factors which come from the surrounding environment such as family, friends and the community. These two factors are experiences in which the fator is able to provide input for life values.
\end{abstract}

Keywords: Trust; Students; Chronic Diseases.

\begin{abstract}
Abstrak
Penyakit kronis merupakan penyakit berbahaya yang tidak bisa dianggap remeh atau diabaikan karena dapat menyebabkan kematian kapan saja, tapi hal tersebut bukan menjadi alasan untuk beberapa mahasiswa di UIN Antasari yang mana mereka tetap menjalani dan melanjutkan kuliah dengan baik walaupun di dalam tubuh mereka ada penyakit yang dapat menyebabkan kematian, hal ini dikarenakan mereka memilih untuk tawakal kepada Allah karena dengan tawakal mereka bisa menjalani kehidupan mereka dengan lebih baik lagi. Maka dari itu peneliti tertarik untuk meneliti gambaran proses tawakal pada mahasiswa yang memiliki penyakit kronis di UIN Antasari Banjarmasin dan faktor yang mempengaruhi sikap tawakal. Penelitian ini menggunakan pendekatan kualitatif. Subjek dalam penelitian ini berjumlah 3 orang mahasiswa UIN Antasari yang memiliki penyakit kronis. Pengumpulan data dalam penelitian ini diperoleh menggunakan teknik observasi Anecdotal Record, dan wawancara semi terstruktur. Setelah data terkumpul kemudian di analisis data dengan tahapan editing, koding,deskripsi serta menyimpulkan data. Berdasarkan hasil penelitian ini terdapat beberapa aspek yang muncul setelah melakukan tawakal seperti timbulnya ketenangan dan kedamaian, menimbulkan kekuatan, Ridha, dan timbulnya harapan. Adapun faktor yang mempengaruhi perilaku tawakal yaitu, pertama faktor lingkungan yang mana faktor ini berasal dari
\end{abstract}


lingkungan sekitar seperti keluarga, teman maupun masyarakat. Kedua faktor pengalaman yang mana faktor ini mampu memberikan masukan untuk nilai-nilai kehidupan.

Kata kunci: Tawakal; Mahasiswa; Penyakit Kronis.

Setiap orang pasti pernah terserang penyakit baik penyakit ringan maupun kronis. Hal itu dikarenakan tubuh manusia tersusun atas berbagai macam organ dan juga jaringan sel yang sangat rentan terserang berbagai macam bibit-bibit penyakit. Pola hidup yang tidak sehat disertai tingkat kebersihan yang tergolong cukup rendah sering kali membuat berbagai macam organ yang ada di dalam tubuh manusia menjadi terserang penyakit. Perlu diketahui juga bahwa penyakit tidak hanya dialami oleh orang yang sudah tua saja, tetapi orang yang masih muda juga dapat mengalami penyakit seperti halnya mahasiswa.

Penyakit disini diartikan sebagai kondisi tidak normalnya sebuah perangkat organ yang ada didalam tubuh manusia yang mana dapat menyebabkan rasa sakit yang dapat mengancam keberlangsungan hidup si penderita (Ratna Dewi, 20015) menurut Elizabeth J. Crown penyakit adalah perihal kehadiran seperangkat respons tubuh yang abnormal terhadap agen, dimana manusia mempunyai toleransi sedikit atau tidak sama sekali, dan juga penyakit memiliki beberapa jenis antara lain: Penyakit menular, penyakit tidak menular, dan penyakit kronis. Penyakit menular adalah penyakit yang disebabkan oleh kuman yang menjangkiti tubuh manusia. Contoh penyakit-penyakit tersebut adalah: Anthrax. malaria, DBD, TBC, rabies, flu burung, dll. Penyakit tidak menular adalah penyakit yang tidak disebabkan oleh kuman, tetapi disebabkan karena adanya problem fisiologis atau metabolisme pada jaringan tubuh manusia. Contohnya: Batuk, sariawan, sakit perut, gangguan jiwa, dll. Penyakit kronis adaalah penyakit yang berlangsung lama. Adapun penyakit kronis yang sering menyebabkan kematian si penderita adalah: AIDS, serangan jantung, kanker, dll.

Penyakit kronis adalah penyebab dari kesakitan dan kematian yang membutuhkan jangka waktu lama dan respon yang kompleks serta tidak jarang biasanya penyakit itu sulit untuk di sembuhkan. Sehingga menerima suatu penyakit bagi seorang penderita tidaklah terjadi dengan begitu saja karena si penderita harus memiliki pikiran positif terhadap penyakitnya dan menganggap penyakitnya bukanlah suatu kutukan, tetapi merupakan bentuk 
kasih sayang Sang Pencipta kepada dirinya, sehingga si penderita mampu untuk menerima kodratnya dengan segala kekurangan dan kelemahannya (Hesti Badaria dan Yulianti Dwi, 2004).

Adapun permasalahan lainnya adalah penyakit kronis tidak hanya menyerang orang yang sudah tua saja, tetapi kaum mudapun juga ikut mengalami penyakit tersebut yang mengakibatkan mereka harus selalu menjalani berbagai macam pengobatan yang kadang malah membuat penyakit lain muncul sehingga mengharuskan mereka dirawat di Rumah Sakit dan akhirnya mereka tidak bisa kegiatan secara penuh seperti kegiatan belajar di perguruan tinggi bagi para mahasiswa, dan hal inilah yang di alami oleh tiga orang Mahasiswa di UIN Antasari Banjarmasin, mereka juga mengalami beberapa penyakit serius dan mengharuskan mereka menjalani berbagai macam pengobatan serta terapi yang terus menerus dan hasilnya ada penyakit yang sembuh atau malah ada penyakit lain yang muncul atau bahkan kambuh, dan karena penyakit inilah tidak jarang membuat orang-orang yang mengalaminya itu menjadi tawakal kepada Allah. Tawakal itu penting pada diri mahasiswa sebab akan mendorong diri mereka yakin akan pertolongan Allah sehingga membuat mereka tetap semangat dalam menjalani kehidupan ini.

Hal ini menunjukkan bahwa sikap tawakal merupakan hal yang terpenting ada dalam diri manusia, karena tawakal sendiri adalah kepercayaan dan penyerahan diri kepada takdir Allah dengan sepenuh jiwa dan raga (Tamami, 2011) dan dengan sikap tawakal ini manusia dapat menunjukan sikap penyerahan dirinya terhadap Sang Pencipta dengan sepenuh jiwanya dan pasrah akan takdirnya setelah berbagai usaha yang dia lakuan. Maka dari itu penulis tertarik utuk melakukan penelitian secara mendalam yang dituangkan dalam bentuk skripsi denga judul Gambaran Tawakal pada Mahasiswa yang Mengalami penyakit kronis di UIN Antasari Banjarmasin.

\section{Metode}

Metode penelitian yang digunakan peneliti adalah metode kualitatif deskriptif. Cara pengumpulan sampel dalam penelitian ini adalah menggunakan purposive sampling yaitu berdasarkan kepada ciri-ciri yang telah ditentukan serta dimiliki oleh subjek yang telah dipilih 
(Haris Herdiansyah, 2010). Adapun objek dalam penelitian ini adalah gambaran tawakal pada mahasiswa yang memiliki penyakit kronis. Teknik pengumpulan data menggunakan wawancara dan observasi Anecdotal Record.

\section{Hasil}

Berdasarkan hasil wawancara ketiga subjek mempunyai penyakit kronis yang berbedabeda seperti subjek AR yang memiliki beberapa penyakit kronis yang diawali dengan usus buntu, dan setelah usus buntunya di oprasi dan terjadi komplikasi yang mengakibatkan infeksi usus kecil, setelah itu juga ada tipes, maag kronis, tumor dan kista yang sudah subjek alami sejak kelas 2 MA dan terus berlanjut sampai sekarang yang terkadang mengharuskan subjek beberapa kali dirawat di Rumah Sakit dan bahkan sampai masuk ICU. Adapun gejala-gejalanya tersebut seperti nafsu makan menurun, mudah lelah, perut terasa sakit dibagian sebelah kanan, susah buang air besar dan kalau makan terasa mual, dan selain itu subjek juga harus menjalani berbagai macam pengobatan untuk bisa sembuh dari penyakitnya tersebut.

Subjek NR juga divonis dokter mempunyai penyakit kronis seperti kanker payudara yang subjek alami sekitar 1 tahunan atau 6 bulan yang lalu pada saat subjek semester 4. Gejala yang subjek alami itu seperti munculnya benjolan disebelah kiri yang mana benjolan itu terus membesar dan mengharuskan subjek melakukan berbagai macam pengobatan. Subjek AY juga divonis mempunyai maag kronis sejak awal perkuliahan atau semester 1 yang mengharuskan subjek dirawat di Rumah Sakit. Gejala-gejala maag ini sudah subjek rasakan sejak SD seperti ketika subjek sarapan pagi itu terasa mual sehingga hal tersebut menyebabkan subjek malas untuk sarapan dan itu terus berlanjut sampai SMP dan SMA, tapi pada waktu SMP subjek sudah bisa merasakan perbedaannya seperti beberapa kali lemas dan pingsan akibat sakit yang hebat dibagian lambung, dan untuk menangani masalah penyakit tersebut ketiga subjek menjalani berbagai macam pengobatan dan itu merupakan salah satu usaha atau ikhtiar yang mereka lakukan, selain itu mereka juga tidak lupa berdoa dan tawakal kepada Allah karena mereka meyakini bahwa penyakit berasal dari Allah maka Allah pula lah yang bisa menyembuhkan, sehingga ketiga subjek tidak takut lagi ketika menghadapi penyakitnya 
karena dengan tawakal dapat membuat ketiga subjek merasakan ketenangan dan memunculkan motivasi didalam dirinya.

\section{Pembahasan}

Perlu kita ketahui bahwa penyakit menjadi bagian dari kehidupan manusia. Tanpa penyakit manusia sering melupakan arti sehat. Jika seseorang menderita sakit, sering kali aktivitasnya terganggu sehingga upayanya untuk menuju kondisi sehat akan diusahakan (Imam Faisal Hamzah, 2014). Kesehatan merupakan hal yang terpenting yang harus dijaga, karena ketika seseorang mengalami sakit apalagi sakit kronis maka akan sulit untuk mendapatkan kesehatan kembali.

Penyakit kronis didefinisikan sebagai suatu keadaan sakit atau ketidakmampuan baik itu psikis, kognitif maupun emosi, berlangsung minimal 6 bulan yang memerlukan intervensi medis secara terus menerus untuk merawat episode akut atau masalah kesehatan yang timbul berulang (Elva Sujana, 2017). Menurut Mayo Penyakit kronis merupakan penyakit dengan ciri bersifat menetap, menyebabkan ketidakmampuan pada penderitanya, dan untuk menyembuhkannya penderita perlu melakukan perawatan dalam periode waktu yang lama.

Kondisi Psikologi orang yang memiliki penyakit kronis itu seperti merasa malu, sedih dan tidak percaya diri, serta gangguan psikologis yang lain seperti terjadinya stres sampai mengalami kecemasan yang berat. Hasil penelitian Dejean et al yang menyatakan pasien dengan penyakit kronik yang mengalami depresi dan kecemasan sehubungan dengan kondisi fisik yang dialaminya (Ratna Dew, 2015). Sedangkan menurut Miler, dkk mengatakan bahwa kecemasan akibat penyakit kronis berhubungan dengan penyakit kronis yang dapat menyebabkan kematian. Hal itu karena kesembuhan penyakit kronis masih tidak dapat dipastikan dan proses perkembangan penyakit tidak dapat diketahui.

Memiliki sebuah penyakit bukanlah suatu yang mudah apalagi itu penyakit kronis yang mana penyakit tersebut membuat mereka sulit menerima kenyataan tersebut, dan bahkan membuat mereka putus asa. Oleh karena itu, penting bagi mereka untuk selalu sabar dan tawakal dalam menghadapinya, karena hanya dengan sabar dan tawakal mereka dapat menjalani kehidupan dengan baik. 
Perlu diketahu bahwa tawakal sendiri merupakan penyerahan penyelesaian dan keberhasilan suatu urusan kepada Allah. Zubaidi berkata di Taajul 'Aruus, tawakal adalah percaya total dengan apa yang ada di sisi Allah, dan memutus harapan apa yang di tangan manusia. Tawakal adalah penyandaran diri kepada Allah dan melakukan ikhtiar, dengan meyakini bahwa Allah adalah Dzat yang Maha Memberi Rezeki, Pencipta yang Menghidupkan, dan yang Mematikan. Tawakal mencakup permohonan total kepada Allah, supaya memberikan pertolongan dalam melakukan apa yang Dia perintahkan, juga dalam hal bertawakal untuk mendapatkan sesuatu yang tidak mampu didapatkannya (Muh. Mu'inudinillah Basri, 2008).

Adapun aspek yang menunjukkan proses tawakal seseorang menurut Yusuf Qardhawi antar lain sebagai berikut: 1. Timbulnya ketenangan dan ketenteraman. 2. Menimbulkan kekuatan. 3. Al-Izzah (Kemuliaan). 4. Sikap ridha. 5. Timbulnya harapan dan keyakinan diri.

Aspek pertama yaitu timbulnya ketenangan dan ketenteraman, yang mana hal ini mereka divonis mempunyai penyakit kronis mereka sangat kaget dan bahkan tidak percaya terhadap apa yang disampaikan oleh Dokter yang menangani mereka, selain itu perasaan takut pun juga muncul dalam diri mereka, Maka dari itu fase ini merupakan fase awal penerimaan diri yang mana pada fase awal ini subjek mengalami yang namanya fase Denial atau fase penyangkalan yang mana menurut Kubler Ross fase ini berisi penolakan diri terkena penyakit atau tidak menerima bahwa dirinya akan mengalami kematian, sehingga yang terjadi selanjutnya adalah perasaan sedih, takut, dan bahkan putus asa seperti teori menurut Agustinia yang mengatakan bahwa ketika seseorang divonis mengidap penyakit kronis maka, sangat berdampak dengan psikologinya, seperti sedih, cemas, putus asa, dan ketakutan dalam hidupnya. Berbeda dengan ke dua subjek AR dan NR, subjek AY lebih menganggap biasa-biasa saja ketika subjek divonis mempunyai maag kronis, tapi walaupun begitu perasaan takut itu tetap muncul dalam diri subjek karena apabila maag yang diderita subjek tambah parah lagi maka akan ada kemungkinan itu bisa menyerang ke hati, untuk itu penting adanya tawakal dalam diri subjek untuk memunculkan perasaan tenang dan kedamaian. 
Aspek menimbulkan kekuatan ketika menjalani proses pengobatan ini ketiga subjek mengatakan bahwa mereka juga pernah merasakan perasaan putus asa dikarenakan ketika menjalani pengobatan tersebut penyakit mereka masih tidak sembuh, maka dari itu untuk menangani hal ini ketiga subjek memilih untuk menyerahkan semuanya kepada Allah karena Allah lah yang berkuasa mengangkat penyakit serta menyembuhkannya selain itu, penting adanya dukungan dari orangorang sekitar, yang mana menurut ketiga subjek ini, orang tua, keluarga serta temanteman adalah orang-orang yang selalu memberikan dukungan dan motivasi untuk ketiga subjek.

Gambaran ridha yang tergambar dalam tiga subjek ini adalah ketika subjek AR dan NR yang awalnya merasakan perasaan sedih dan perasaan-perasaan yang ingin menjalani aktivitas seperti orang lain yang tidak mempunyai kesulitan ketika harus menjalani aktivitasnya, tapi perasaan itu dapat diatasi dengan mengembalikan lagi kepada Allah, selain itu subjek NR juga memperbanyak istigfar dan bersyukur ketika menghadapinya. Berbeda dengan subjek AR dan $\mathrm{NR}$, subjek AY lebih menganggap biasa-biasa saja terhadap penyakit yang subjek alami karena menurut subjek penyakit maag itu masih bisa diobati walaupun kalau sudah parah itu dapat menyerang ke hati, dan itu pun tergantung dari yang punya tubuh. Selain itu, ketika ketiga subjek ditanya terhadap pandangan mereka terhadap penyakit mereka, mereka memandang penyakitnya adalah ujian dan pembelajaran bagi mereka yang mana ketiga subjek ini harus bersyukur dan menghargai kesehatan yang diberikan Allah serta menyikapinya dengan cara sabar dan menyerahkan semuanya kepada Allah karena Dialah berkuasa atas semua itu dan juga tidak lupa diiringi dengan usaha.

Aspek timbulnya harapan yaitu orang yang bertawakal kepada Allah tidak mengenal putus harapan dan tidak akan dikalahkan oleh rasa putus asa, dalam hal ini ketiga subjek mengatakan bahwa usaha yang mereka lakukan untuk bisa sembuh itu cukuplah besar, selain itu motivasi juga penting bagi ketiga subjek yang mana untuk memotivasi dirinya ketiga subjek meyakinkan diri mereka kepada Allah seperti subjek AR yang meyakini setiap yang terjadi tidak akan terjadi atas izin Allah, dan subjek NR meyakini bahwa ada hikmah dibalik semua 
ini, sedangkan subjek AY meyakini bahwa sakit adalah penggugur dosa. Adapun yang membuat ketiga subjek bisa bertahan yang pastinya adalah adanya dukungan dari keluarga dan orang-orang sekitar yang selalu memotivasi mereka.

Adapun faktor yang mempengaruhi ketiga subjek dalam tawakal seperti faktor lingkungan yang mana menurut ketiga subjek orang tua dan keluarga merupakan sumber kekuatan buat subjek yang selalu mengingatkan subjek sehingga, dalam menyikapi penyakit subjek, orang tua serta keluarga subjek lebih menganggap bahwa itu semua adalah cobaan atau ujian buat subjek sehingga subjek harus sabar dalam menyikapinya. Faktor berikutnya adalah faktor pengalaman, yaitu faktor yang mampu memberikan masukan untuk nilai-nilai hidup dari pengalaman tersebut. Maka dari itu pengalaman merupakan hal yang penting untuk ketiga subjek ini karena pengalaman adalah pembelajaran bagi ketiga subjek ini.

\section{Kesimpulan}

Berdasarkan hasil penelitian yang telah dilakukan maka peneliti dapat menyimpulkan bahwa orang yang bertawakal, dia akan percaya dan menyerahkan diri kepada takdir Allah dengan sepenuh jiwa dan raga. Penyerahan diri kepada Allah dapat di artikan sebagai menyerahkan segala urusan kepada takdir Allah, yang mana ketika seseorang menyerahkan semuanya kepada Allah maka dia pun tidak akan merasa cemas dan gelisah terhadap akibat apapun yang menimpa dirinya, dan dalam penelitian ini juga terdapat beberapa aspek yang muncul setelah melakukan tawakal seperti timbulnya ketenangan dan kedamaian, menimbulkan kekuatan, Ridha, dan timbulnya harapan.

Faktor yang mempengaruhi perilaku tawakal yaitu, pertama faktor lingkungan yang mana faktor ini berasal dari lingkungan sekitar seperti keluarga, teman maupun masyarakat. Kedua faktor pengalaman yang mana fator ini mampu memberikan masukan untuk nilai-nilai kehidupan.

\section{Saran}

Bagi subjek penelitian diharapkan agar selalu tawakal dalam menghadapi situasi apapun dan juga diiringi dengan usaha dan bagi peneliti selanjutnya penelitian ini diharapkan dapat 
membantu penelitian berikutnya dalam pembuatan skripsi, jurnal atau pun publikasi ilmiah, juga disarankan agar melakukan penelitian dengan sudut pandang berbeda dan perluasan subjek agar data yang didapatkan lebih luas lagi.

\section{Referensi}

Basri, Muh. Mur'inudinillah. Indahnya Tawakal. Solo: Indiva Media Kreasi, 2008.

Dewi, Ratna. "Pengalaman Mahasiswa Dengan Penyakit Kronis Dalam Belajar Di Universitas Esa Unggul." Jurnal Keperawatan. Vol. 1, No. 1, Maret 2016.

Hamzah, Imam Faisal dkk. "Makna Sakit Pada Penderita Penyakit Jantung Koroner: Studi Fenomenologis." dalam Jurnal Psikologi. Vol. 13, No. 1, April 2014.

Herdiansyah, Haris. Metode Penelitian Kualitatif untuk Ilmu-ilmu Sosial. Jakarta: Salemba Humanika, 2010.

Qardhawi, Yusuf. Risalah Ikhlas dan Tawakal. Solo: Aqwam, 2015.

Sujana, Elva dkk. "Kebutuhan Spritual Keluarga dengan Anak Penderita Penyakit Kronis." Jurnal Pendidikan Keperawatan Indonesia. Vol. 3, No. 1, 2017.

Tamami. Psikologi Tasawuf. Bandung: Pustaka Setia, 2011.

\begin{tabular}{|l|l|l|l|l|}
\hline Submit & Review & Revisi & Diterima & Publis \\
\hline 23-02-2020 & - & - & $03-02-2021$ & $22-04-2021$ \\
\hline
\end{tabular}

Munirah, Yulia Hairina, dan Mubarak

Program Studi Psikologi Islam

Fakultas Ushuluddin dan Humaniora

Universitas Islam Negeri Antasari Banjarmasin

E-mail: munirahdazu@gmail.com 